\title{
Does microfinance program innovation reduce income inequality? Cross-country and panel data analysis
}

\author{
Kamel Bel Hadj Miled ${ }^{1,2^{*}}$ (D), Moheddine Younsi ${ }^{3,4}$ and Monia Landolsi ${ }^{5}$
}

\author{
${ }^{*}$ Correspondence: \\ kamelbenmiled@gmail.com \\ ${ }^{1}$ Department of Business \\ Administration, College \\ of Science and Arts, Shaqra \\ University, Sajir, Saudi Arabia \\ Full list of author information \\ is available at the end of the \\ article
}

\begin{abstract}
This paper uses cross-country and panel data set to test the significance of microfinance on income inequality reduction at the macro level for a sample of 57 developing countries for the periods 2000-2006 and 2007-2013. This study adopts panel data methodologies, such as ordinary least square (OLS), pooled ordinary least square (POLS) and instrumental variables (IV) estimations to overcome the endogeneity problems among the variables. Empirical results show that countries with higher MFIs' gross loan portfolio per capita tend to have lower income inequality, which confirm the beneficial outcome of microfinance in reducing inequality at the macro level. Moreover, our results suggest that microfinance loans can lead to improve the relative income position of the poor in developing countries, albeit slowly. Our findings have relevant recommendations to policymakers, as they could generate suitable strategies to consider microfinance institutions as a more popular tool for fighting against both poverty and inequality.
\end{abstract}

Keywords: Microfinance, Income inequality, Loan portfolio, Instrumental variables, Macro-level analysis

JEL Classification: C31, G21, 132, O15

\section{Introduction}

Though some negative issues especially those about over indebtedness and high interest rates are discussed as well, microfinance remains as an effective and innovative tool for reducing poverty and income inequality. In the recent decades, the issue of poverty and inequality remains one of the major problems in the economic development field, especially in poor developing countries. Therefore, understanding the role that microfinance program innovation plays in reducing poverty and income inequality is an issue of great importance to the poor people of developing countries, where providing financial access such as microfinance to the poorest seems to be a panacea for reducing poverty (Johnson \& Rogaly, 1997; Gibbons \& Meehan, 2002), (Armendariz \& Morduch, 2005; Bakhtiari, 2011; Beck et al., 2007; Bel hadj Miled \& Ben Rejeb, 2018; Hossain \& Knight, 2008; Imai et al., 2012; Roodman \& Jonathan, 2014) and income inequality (Bangoura et al., 2016; Beck et al., 2004; Hermes, 2014; Kai \& Hamori, 2009; Lacalle-Calderon et al., author(s) and the source, provide a link to the Creative Commons licence, and indicate if changes were made. The images or other third party material in this article are included in the article's Creative Commons licence, unless indicated otherwise in a credit line to the material. If material is not included in the article's Creative Commons licence and your intended use is not permitted by statutory regulation or exceeds the permitted use, you will need to obtain permission directly from the copyright holder. To view a copy of this licence, visit http:// creativecommons.org/licenses/by/4.0/. 
2019; Tchouassi, 2011). The microfinance industry carries every sign of an innovation in its take-off phase (Mersland \& Strøm, 2012).

Indeed, the dynamics of microfinance program innovation can be recognized from social and economic perspectives. From the social perspective, microfinance can help the poor by reducing barriers to access credit, thereby increasing access of the poor to financial services, providing safety-net and consumption smoothening and increasing women's self-employment opportunities and access to education (Kabeer, 2005; Fishman, 2012; Kumar, 2016). From the economic perspective, microfinance institutions, which are profit-seeking institutions, play a significant role in the fight against both poverty and inequality (Ahlin \& Jiang, 2008; Beck et al., 2004; Odell, 2010) that was one of the United Nations Millennium Development Goals (MDGs) development agenda until the year 2015. One important channel through which poverty can be reduced is by tackling income inequality, because the income distribution can affect the level of poverty through its impact on economic growth (Besley \& Burgess, 2003; Bhargava, 2006; Bourguignon, 2004; Ravallion, 2005; Soubbotina \& Sheram, 2000). Pro-poor growth can be achieved when the incomes of the poor grow at a higher rate than the incomes of the non-poor (Jalilian \& Kirkpatrick, 2005; Hermes, 2014).

Several studies have argued that the lack of access to finance by the poor is one of the most barriers that impede that state to eradicate its level of poverty or income inequality (Hulme \& Mosley, 1996), Beck \& Demirgüç-Kunt, 2008; Cuong, 2007; McKenzie \& Woodruff, 2008). So that, it can be argued that microfinance represents an extremely powerful tool to achieve pro-poor growth as they disproportionately benefit the poor. Microloans is an alternative to traditional finance which gives to the poor the opportunity to increase their incomes since it can be used for self-employment and other income-generating activities (Ahlin \& Jiang, 2008; Banerjee \& Jackson, 2017; CastellsQuintana et al., 2019; Roodman \& Jonathan, 2014). The provision of microloans gives the poorest segments of the world population access to funds allowing them to maintain their standard of living and economic activities or create new ones (Ahlin \& Jiang, 2008; Banerjee et al., 2015). Since, the modern microfinance model offers a wide range of potentially beneficial products (e.g., savings, insurance, money transfers) that can lead to enhanced access to health and education (Morduch \& Haley, 2002). Because microfinance in developing countries is mainly focused on the poor, it can be argued that the provision of microfinance helps reducing the level of income inequality as it disproportionately raises the incomes of the poor as compared to the rich.

Although there are various success stories of microfinance, it has been the subject of many criticisms that have sparked an important debate among academics and practitioners about its influence and sustainability (Ali \& Ghoneim, 2019; Banerjee \& Newman, 1993; Castells-Quintana et al., 2019; Cull et al., 2011; Dabla-Norris et al., 2015; Ghosh, 2013; Hermes, 2014). The link between microfinance and income inequality still remain controversial as the true relationship has not been identified. We therefore aim to test the significance of microfinance on income inequality using cross-country and panel data set for 57 developing countries for the periods 2000-2006 and 2007-2013. The findings are useful to development agencies, governments and other investors as they have important implications for the potential role of microfinance in reducing inequality at the macro level. The challenges of macro-empirical research on microfinance 
include: (a) determine appropriate measurement standards for microfinance activities based on "availability" or "intensity"; (b) determine the effect of "performance" distinguished from "presence" and "scale" of microfinance on macro indicators; and (c) check the robustness of the estimated parameters related to microfinance.

This work contributes to the literature in the following ways. First, we treat microfinance as a financial system that directly affects income inequality. Second, we provide a more in-depth discussion of the outcomes regarding the linkage between microfinance and income inequality. Third, we used a cross-border panel data of 1132 microfinance institutions in 57 developing countries, which has the advantage to include the individual dimension through a two-period 2006 and 2013 (Gini coefficient data for the panel were constructed by taking averages for the period of 2000 to 2006 and 2007 to 2013). Fourth, this paper adopted panel data methodologies, such as ordinary least square (OLS), pooled ordinary least square (POLS) and instrumental variables (IV) estimations to overcome the endogeneity problem among the variables. We found strong evidence that microfinance has a significant negative impact on income inequality, indicating that countries with high level of microloans provision are generally associated with lower levels of income inequality.

The rest of the paper is organized as follows. "Literature review" Section draws an overview of the literature on the relationship between microfinance and income inequality. "Data and methodology" Section describes the data, the variables and the econometric framework. "Empirical results and discussion" discusses the empirical results. "Conclusion and policy implications" concludes and suggests some policy implications.

\section{Literature review}

The microfinance industry carries every sign of an innovation in its take-off phase. We trace the innovations in microfinance for instance group lending, loans to women, and their financing. Thus, microfinance gives poor people and small businesses access to financial services (Afrane, 2002; Barnes, 1996; Mersland \& Strøm, 2012). While the existing literature reveals that though research on the linkage between microfinance and poverty using different set of countries, data and estimation techniques are voluminous, less attention has been paid to inequality and there are a few recent works that have addressed the impact of microfinance program innovation on income inequality at the macro level.

For example, Ahlin and Jiang (2008) examined the long-run effects of microcredit on development, measured by per capita income, inequality and poverty, by using an occupational choice model proposed by Banerjee and Newman (1993). The empirical results revealed that microcredit contributes to lower long-run inequality and poverty by making subsistence payoffs less widespread and increasing the income of the poor people. By employing the computable general equilibrium (CGE) model from 1999 to 2000, Mahjabeen (2008) found that microfinance in Bangladesh reduces inequality and improves social welfare. This study suggested that microfinance is one of the required critical interventions for empowering the poor people. Kai and Hamori (2009), and Tchouassi (2011) used a cross-country empirical study to investigate the effect of microfinance on income inequality in developing countries, including those in Africa. The authors measured the degree of microfinance intensity by both the number of MFIs and the number 
of active borrowers from MFIs. The empirical results revealed that income inequality is negatively and significantly influenced by microfinance intensity. Their studies suggested that microfinance intensity plays a key role in creating a financial system endowed with the equalizing effect.

Hermes (2014) examined the impact of microfinance on income inequality for 70 developing countries for the period 2000-2008 using Ordinary Least Squares (OLS) and instrumental variables (IV) estimations, and two different measures of microfinance intensity, i.e. the number of active borrowers divided by the country's total population and the total value of microfinance loans to GDP ratio. The empirical findings revealed that microfinance has relatively little effect on reducing income inequality in these countries due to their relatively small microfinance sectors. Using heterogeneous panel causality techniques, Bangoura et al. (2016) examined the relationship between microfinance and its effects on poverty and inequality for a panel of 52 developing countries over the period 1996-2011. The effect of microfinance is measured through two intensity indicators, i.e. the number of active borrowers from MFIs and the volume of loans. The empirical results showed that microfinance intensity has a significant negative effect on income inequality, suggesting that countries with high level of microfinance intensity, is generally associated with a decreased level of income inequality. Their findings further suggested that providing access to loans through microfinance offers to the poor the possible for income-generating activities. More recently, LacalleCalderon et al. (2019) found that microfinance has an egalitarian effect on income inequality in 85 countries over the period 2001-2012. The study further indicated that an increased in the macro-scale of microfinance activities in a country could be one effective tool for reducing country's inequality, among others. Arif et al. (2019) examined the effect of microfinance on poverty reduction and inequality for 33 provinces in Indonesia from 2011 to 2016 and found that higher level of microfinance significantly reduces poverty but it cannot be done to reduce income inequality. Using cross-country analysis data for 30 developing countries from 2013 to 2015, Ali and Ghoneim (2019) analyzed the effect of microfinance on income inequality by including two different measures of microfinance intensity, that is, the number of active borrowers and the value of microfinance loans. Their empirical results revealed that both measures of microfinance are still too weak to reduce income inequality. Castells-Quintana et al. (2019) examined the relationship between aid, microfinance and its effects on income inequality using a panel data set covering 87 developing countries during the period 1995-2012. The empirical evidence revealed that microfinance seems not to be a panacea for reducing income inequality. It was further suggested that the effect of microfinance intensity on inequality is extensively depending on the country-specific context.

\section{Data and methodology}

\section{Data and variables}

In the present study, we use cross-sectional data covering 596 microfinance institutions for 2013, supplemented by a two-period (span from 2000 to 2006 and 2007 to 2013) panel data set of 57 developing countries in 1132 microfinance institutions with high levels of informational transparency. The sample data include 12 countries in Europe and Central Asia (ECA), 10 in East Asia and Pacific (EAP), 13 in Latin America and 
Caribbean (LAC), 3 in South Asia (SA), 16 in Sub-Saharan Africa (SSA), and 3 in Middle East and North Africa (MENA). A complete list of countries is provided in Appendix: Table 5 .

Following preceding studies (Beck et al., 2004, 2007; Kim \& Lin, 2011; Li et al., 1998; Younsi \& Bechtini, 2018; Younsi et al., 2019), we consider our dependent variable as Gini coefficient (income inequality). In line with earlier studies (Delbianco et al., 2014; Dollar \& Kraay, 2002; Herzer \& Vollmer, 2012; Shahbaz et al., 2017; Stewart \& Moslares, 2012; Stiglitz, 2012), real GDP per capita (in constant international dollars) is considered. Furthermore, country-level control measures are included, namely, trade openness (Dreher \& Gaston, 2008; Franco \& Gerussi, 2013; Kai \& Hamori, 2009; Milanovic, 2002; Reuveny \& Li, 2003; Silva, 2007; Zhu \& Trefler, 2005) and domestic credit to private sector (Beck \& Levine, 2002; Beck et al., 2007; Jauch \& Watzka, 2016; Kim \& Lin, 2011). All data were obtained from the World Development Indicators (WDI) (World Bank, 2013) database (http://data.worldbank.org/indicator). Data on microcredit gross loan portfolio divided by the country's total population (GLF) as a proxy to measuring microfinance activities are from Microfinance Information Exchange (MIX) market database. Although this database contains data since 1995, only the data since 2000 are sufficient and meaningful. Today, the MIX market database contains information provided more than 2000 microfinance institutions (MFIs) around the world covering nearly 100 million borrowers. Total gross loan portfolio of MFIs aggregated for each country is adjusted for write-offs and inflation. Moreover, Latin America and Caribbean Dummy are included as dummy variables for the Latin America and Caribbean region, which takes the value 1 if a country belongs to this region and 0 otherwise. This region is considered to comprise countries with lower levels of income inequality in the developing regions for the year 2013.

It is noticed that the records collected from these sources are matched by country and year, after removing the country-year observations that cannot be matched correctly, we were left with an unbalanced panel-data set covering a total of 57 developing countries over a two-period interval (span from 2000 to 2006 and 2007 to 2013). Data restrictions such as missing values restrict the analysis to this period, and focus on the 3-5 diamond levels which are the highest level of disclosure to its outreach, impact and financial data, audited financial statements and rating/evaluations. Table 1 provides summary statistics for the variables used in the empirical analysis. For each of the variables, we computed the mean and median statistics by region.

\section{Econometric model}

We estimate a specification model similar to Milanovic (2002), Kai and Hamori (2009), Tchouassi (2011) and Hermes (2014), where variation in income inequality across countries is regressed on microfinance and a set of control variables:

$$
\begin{aligned}
& I N E Q_{i}=\alpha_{0}+\alpha_{1} G L F_{i}+\beta X_{i}^{\prime}+u_{i} \\
& G L F_{i}=\beta_{0}+\beta_{1} C E_{i}+\beta_{2} L n 5 G L F_{i}+\beta_{3} Y_{i}+\Omega_{i}
\end{aligned}
$$


Table 1 Summary statistics

\begin{tabular}{|c|c|c|c|c|c|c|c|c|c|c|c|c|c|}
\hline & & \multicolumn{2}{|l|}{ GINI } & \multicolumn{2}{|l|}{ GLF } & \multicolumn{2}{|l|}{ GDP } & \multicolumn{2}{|l|}{$\mathrm{DCP}$} & \multicolumn{2}{|c|}{ TRADE } & \multicolumn{2}{|c|}{ No. of MFIs } \\
\hline & & 2006 & 2013 & 2006 & 2013 & 2006 & 2013 & 2006 & 2013 & 2006 & 2013 & 2006 & 2013 \\
\hline \multirow[t]{2}{*}{ MENA } & Mean & 37 & 35.7 & 2.8 & 13.7 & 1841 & 2270 & 61.7 & 59 & 93.4 & 83 & 9 & 3 \\
\hline & Median & 39 & 35.7 & 2.2 & 18 & 1948 & 2432 & 51 & 71 & 70 & 84 & 10 & 8 \\
\hline \multirow[t]{2}{*}{ SA } & Mean & 35 & 32 & 2 & 6 & 478 & 569 & 30 & 39 & 39.6 & 43 & 37 & 33 \\
\hline & Median & 33 & 32 & 0.9 & 4 & 421 & 568 & 28.6 & 48 & 39.6 & 41 & 28 & 34 \\
\hline \multirow[t]{2}{*}{ SSA } & Mean & 54 & 43 & 2.4 & 4.7 & 449.5 & 500 & 12.7 & 16 & 59 & 62 & 9 & 11 \\
\hline & Median & 55 & 43 & 1 & 2.5 & 375 & 405 & 11 & 17 & 61.4 & 62 & 8 & 9 \\
\hline \multirow[t]{2}{*}{ EAP } & Mean & 38.7 & 38 & 3.5 & 19 & 1019 & 1479 & 46 & 61 & 88.7 & 84 & 36 & 44.7 \\
\hline & Median & 39.5 & 37.7 & 2.7 & 5.5 & 970.5 & 1258 & 34 & 41 & 75 & 61 & 23.5 & 32.5 \\
\hline \multirow[t]{2}{*}{ LAC } & Mean & 54 & 51.8 & 12 & 57 & 3619 & 4099 & 31 & 38 & 68.5 & 75 & 14.75 & 24 \\
\hline & Median & 55 & 51.6 & 7.8 & 43 & 3203 & 3930 & 23 & 36 & 59 & 69 & 13 & 21 \\
\hline \multirow[t]{2}{*}{ ECA } & Mean & 35 & 34 & 15 & 72 & 2549 & 3280 & 22 & 37 & 92 & 95 & 13.5 & 12.6 \\
\hline & Median & 35 & 34 & 13.7 & 84 & 2810 & 343 & 21.7 & 38 & 96 & 88 & 8.5 & 11 \\
\hline
\end{tabular}

MENA Middle East and North Africa, SA South Asia, SSA Sub-Saharan Africa; EAP East Asia and Pacific, LAC Latin America and Caribbean, ECA Europe and Central Asia

Source:Authors' compilations from WDI and MIX databases

where $i=1,2, \ldots, N$ is the country indicator. Equation (1) represents the income inequality (INEQ) measured by Gini coefficient, while Eq. (2) represents gross loan portfolio per capita (GLF), as a proxy for microfinance intensity (after adjusting for inflation). $X_{i}$ represents a vector of control variables including trade openness (TRADE), measured by the sum of exports and imports divided by GDP, per capita GDP (in constant 2000 international dollars), domestic credit to private sector by banks to GDP ratio (DCP), and a set of regional dummy variables, $u$ and $\Omega$ are the stochastic disturbance terms.

We, thus, empirically analyze how a change in MFIs' GLF can affect INEQ. In order to address the problem of endogeneity, we employ the instrumental variable technique to determine each parameter. Equation (2) is the reduced form to test the existence of endogenous variables. However, we use enforcing contracts at the country level (CE) and the weighted 5-year average lag of GLF, which is weighted by the number of MFIs for each country (lnw5lagGLF), while $Y$ is the vector of other explanatory variables considered in Eq. (1).

We adopt ordinary least squares (OLS) and two-stage least squares (2SLS) or instrumental variables (IV) estimates to test the impact of MFIs' GLF per capita on income inequality. The 2SLS comprises two stages: The first stage estimates the GLF per capita of MFIs using instrumental variables and other covariates, while the second stage estimates the INEQ using the predicted GLF per capita and other covariates, a technique for solving endogeneity problems related to the bi-casual relationship between the GLF per capita and the INEQ level in a country. This reverse causality between INEQ and GLF per capita may arise, for example, when INEQ-oriented development partners and governments allocate more resources to MFIs in poorer countries (Imai et al., 2012). Since it is difficult to find a valid instrument that satisfies an "exclusion constraint," that is correlated with GLF per capita but does not have a direct causal 
effect on INEQ, this work uses two types of instruments, cost of enforcing contract and a lag of 5-year average of GLF weighted by the number of MFIs for each country.

The former is intuitively reasonable by the fact that the decision of commercial microfinance investors, especially international funders, decide whether to invest in a particular country is likely to depend on the degree to which the country has good system (e.g., low costs of enforcing contracts) that will promote economic activities. In this case, we assumed that the cost of enforcing contracts has a significant negative correlation with MFI credit per capita. We perform a series of robustness checks among which we used an alternative test of the estimation model. However, since the weak identification test is only $10 \%$ significant in this case, we need to extend the instrumentation. Using both instruments leads to a much higher Kleibergen-Paap rk Wald $F$-statistic (weak identification test), as shown by the $p$ values $(0.0178 ; 0.000)$ in columns 3 and 4 of Table 2 . This does not affect Sargan's over-identification test, as $(0.028 ; 0.070)$ does not reject the null hypothesis, indicating that the instruments are valid, i.e., not correlated with the error term. In addition, the $p$ values $(0.000$ and 0.0023$)$ of the under-identification test observed in columns 3 and 4 of Table 2 allow us to reject the null hypothesis, indicating that the model is under-identified. These specification tests validate the estimates of IV. Nevertheless, treatment with the STATA 12 allows a resolution using OLS and 2SLS estimators.

\section{Empirical results and discussion}

Figure1 plots the variation of median GLF for the selected different regions (after adjusting for inflation).From this graph, it is shown that the median GLF increases for all regions over the sample period, and as can be observed, the variation is remarkably for

Table 2 Results based on cross-sectional regressions

\begin{tabular}{lllll}
\hline Variables & $\begin{array}{l}\text { OLS (without } \\
\text { region) (1) }\end{array}$ & $\begin{array}{l}\text { OLS (with region) } \\
\mathbf{( 2 )}\end{array}$ & $\begin{array}{l}\text { VI (without region) } \\
\mathbf{( 3 )}\end{array}$ & VI (with region) (4) \\
\hline GLF & $-5.00^{* * *}(-4.19)$ & $-2.5^{* *}(-2.32)$ & $-3.61^{* *}(-2.39)$ & $-0.83^{*}(-1.62)$ \\
GDP & $-13.72^{* * *}(-6.81)$ & $-7.31^{* *}(-3.04)$ & $-14.65^{* * *}(-7.08)$ & $-6.99^{* * *}(-3.25)$ \\
DCP & $-0.02(-0.33)$ & $0.03(0.66)$ & $-0.03(-0.47)$ & $0.014(0.36)$ \\
TRADE & $0.71^{* * *}(2.80)$ & $0.31^{* * *}(1.70)$ & $-0.03(-0.47)$ & $0.014(0.36)$ \\
MENA & - & $-13.40^{* * *}(-3.81)$ & - & $-10.80^{* * *}(-4.9)$ \\
LAC & - & $6.62(0.91)$ & - & $8.2(1.30)$ \\
SSA & - & $8.30^{* * *}(3.24)$ & - & $9.60^{* * *}(4.34)$ \\
EAP & - & $0.38(0.44)$ & - & $0.80(1.35)$ \\
ECA & - & $-0.98^{* * *}(-3.14)$ & - & $-1.14^{* * *}(-4.56)$ \\
Constant & $135.60^{* * *}(10.41)$ & $74.68^{* * *}(3.93)$ & $138.80^{* * *}(10.74)$ & $67.13^{* *}(4.11)$ \\
R-sq & 0.70 & 0.80 & 0.83 & 0.89 \\
Under id $(p$ value) & - & - & $33.5(0.000)$ & $12.1(0.0023)$ \\
Weakid $p$ value) & - & - & $4.3(0.0178)$ & $23.4(0.000)$ \\
Over id ( $p$ value) & - & - & $4.8(0.028)$ & $3.208(0.070)$ \\
Hausman & & & $2.18(0.700)$ & $3.87(0.900)$ \\
test(Prob >chi2) & & 57 & 57 & 57 \\
Observations & 57 & & & \\
\hline
\end{tabular}

GLF and GDP variables are in logarithm. OLS denotes Ordinary Least Squares.Figures in brackets show $t$-statistic.Regional dummies with South Asia being the reference region: MENA: Middle East and North Africa, SA: South Asia, SSA: Sub-Saharan Africa; EAP: East Asia and Pacific, LAC: Latin America and Caribbean, ECA: Europe and Central Asia

${ }^{*}, * *$ and ${ }^{* *}$ Indicate statistical significance at the 10,5 and $1 \%$ levels, respectively 


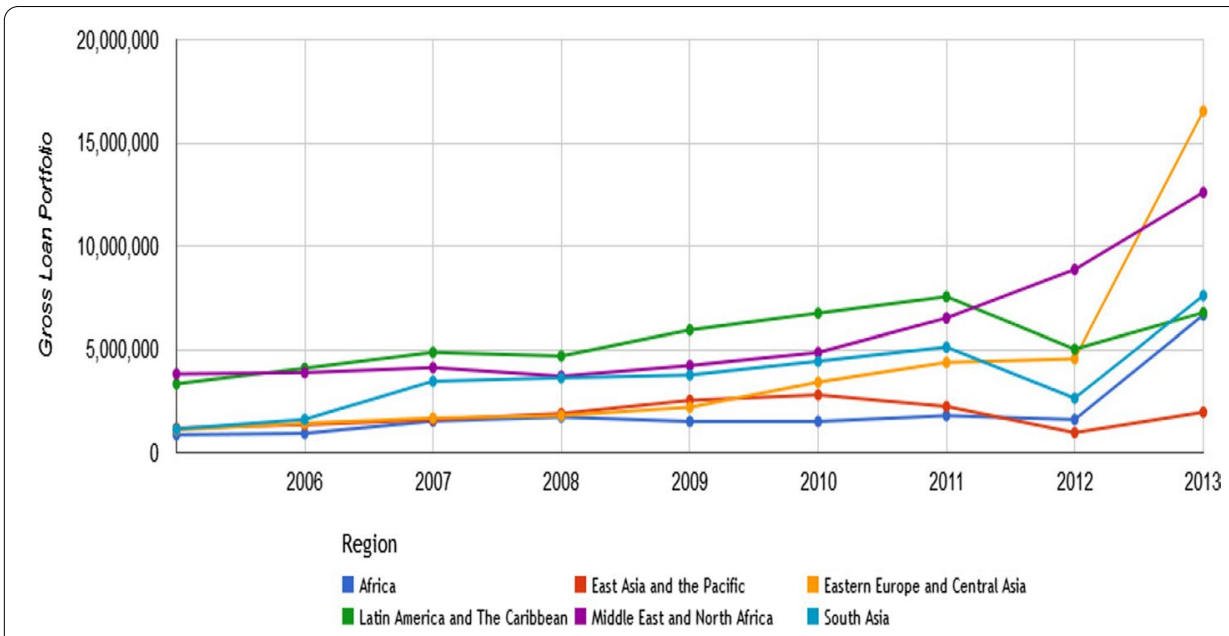

Fig. 1 Trends and patterns of real gross loan portfolio. Source: Authors' compilations from MIX data

Table 3 Results based on panel data regressions

\begin{tabular}{llll}
\hline Variables & POLS (1) & FE (2) & RE (3) \\
\hline GLF & $-0.00028^{* *}(-50.06)$ & $-0.0100(-1.18)$ & $-0.0100^{*}(-1.72)$ \\
GDP & $0.037^{* *}(12.59)$ & $0.0300(0.48)$ & $0.040^{*}(1.81)$ \\
DCP & $-0.001^{* *}(-5.36)$ & $-0.0005(-0.47)$ & $-0.00079(-0.93)$ \\
TRADE & $0.0006(3.51)$ & $-0.00007(-0.16)$ & $-0.06^{*}(-1.8)$ \\
2013yeardummy & $-0.006(-2.40)$ & $0.00005(0.01)$ & $0.0006(0.07)$ \\
MENA & $-0.33^{* *}(-43.10)$ & - & - \\
LAC & $-0.35^{* * *}(-31.29)$ & - & - \\
SSA & $-0.16^{* *}(-12.85)$ & - & - \\
EAP & $-0.16^{* * *}(-138.9)$ & - & - \\
ECA & $-0.44(0.30)$ & - & - \\
Constant & $3.65^{* * *}(81.96)$ & $3.49^{* * *}(6.15)$ & $3.44^{* * *}(19.07)$ \\
R-sq & 0.62 & - & - \\
Hausman test (Prob >chi2) & - & - & $0.43(0.91)$ \\
R-sq. within & - & - & 0.06 \\
R-sq. between & - & - & 0.04 \\
R-sq. overall & - & - & 0.05 \\
Prob > chi2 & - & 114 & 0.21 \\
Observations & 114 & 114 \\
\hline
\end{tabular}

. GLF and GDP variables are in logarithm. 2013 year dummy $(2013=1$, other $=0)$. POLS denote pool Ordinary Least Squares. FE denotes fixed-effects regression. RE denotes random-effects regression. Figures in brackets show $t$-statistic. Regional dummies with South Asia being the reference region: MENA Middle East and North Africa, SA South Asia, SSA Sub-Saharan Africa, EAP East Asia and Pacific, LAC Latin America and Caribbean, ECA Europe and Central Asia

$*^{* * *}$ and ${ }^{* * *}$ indicate statistical significance at the 10,5 and $1 \%$ levels, respectively

the two sub-periods: 2007-2008 and 2011-2012. An interpretation of the trend over these sub-periods needs to take into consideration the potential impact of the global financial crisis on the microfinance industry. In addition to that, Eastern Europe and central Asia, and Middle East and Nord African regions have experienced a sharper increase in the GLF than other regions. Until 2007, the largest MFIs were located in Latin America and the Caribbean. Nevertheless, in 2008, MFIs in Middle East and North Africa experienced a sharp increase in their GLF per capita. 
Tables 2 and 3 present the results of the impact of microfinance intensity (GLF) on income inequality (INEQ). Table 2 reports the result based on cross-sectional data with OLS and IV estimations, while Table 3 reports the result based on panel data using pooled OLS, fixed effect (FE), and random effect (RE) regressions.

Referring to Tables 2 and 3, we conclude that GLF per capita negatively and significantly affects income inequality in all regressions at the 1,5 and 10\% levels respectively, except for FE regression. The results confirm that microfinance intensity plays a decisive role in bringing down income inequality in a significant way. Therefore, providing loans through microfinance provides the poor with the potential for income-generating activities. In addition, the results show that countries with high microfinance intensity are usually associated with lower income inequality, which involves the potential of microfinance to reduce income inequality at the macro level, thus strengthening the development finance institutions and governments of developing countries into microfinance institutions. The results corroborate the studies of Mahjabeen (2008), Kai and Hamori (2009), Tchouassi (2011), Bangoura et al. (2016), and Lacalle-Calderon et al. (2019). Yet, our empirical results are inconsistent with the findings of Hermes (2014), Arif et al. (2019), Ali and Ghoneim (2019), and Castells-Quintana et al. (2019), suggesting providing financial access to the poor cannot reduce the level of income inequality.

With regard to the control variables, the impact of some variables is sensitive to the data and estimation techniques, whether cross-sectional data or panel data regressions. For example, in Table 2, GDP per capita has a negative and a statistically significant impact on income inequality at the $1 \%$ level. On the other hand, in Table 3, GDP per capita positively and significantly affects income inequality except for regression (2). Moreover, domestic credit (\% of GDP) has a negative but insignificant impact on income inequality, except for regressions (2) and (4). On the other hand, in Table 3, it has a negative and a statistically significant effect on income inequality at the $5 \%$ level only in regression (1). The relatively small impact of financial development on income inequality is probably due to the inequality of financial development between countries and regions. The financial sector in low-income countries is not yet sufficiently developed and illiquid, limiting access to long-term financing, and therefore reduces the ability of different countries of the sub-group to be financed by local debt. The results also show that trade openness aggravates income inequality, as shown in Table 2; it has a positive and a statistically significant impact on income inequality at the $1 \%$ level only in regressions (1) and (2). While in Table 3, it shows that trade openness negatively and significantly impairs income inequality at the $10 \%$ level only in regression (3). The fairly small impact of trade openness on income inequality can be explained by the increase in manufacturing exports which reinforced the amplitude of inequalities, consistent with the results of Hamori and Hashiguchi (2012) suggesting that trade openness has not a beneficial effect on reducing income inequality.

As for the impact of regional dummy variables on the incidence of income inequality (see Table 2), we show that MFIs' GLF per capita and GDP per capita remain statistically significant after inclusion of regional dummy variables. However, the inclusion of the regional dummy variables reveals that Middle East and North Africa (MENA) with South Asia (SA) as the reference case, have a negative and significant coefficient (at the $1 \%$ level as in the case of OLS and IV estimation). In addition, Latin America and 
Caribbean (LAC) and Sub-Saharan Africa (SSA) dummies are positive in the OLS estimation. This implies that LAC and SSA have higher income inequality levels relative to SA.

As discussed earlier, the endogeneity may be due to a bi-causal relationship between income inequality and gross loan portfolio per capita. In terms of a bi-causal relationship between GLF per capita and income inequality, we allude to the fact that investors who are inclined to income inequality reduction might direct their financial resources to countries and regions where income inequality is high. In our study, we check the validity of our instruments by using two robust tests for identification, such as: weak-identification and under-identification tests (Kleibergen \& Paap, 2006), as shown in Table 2 (columns 3 and 4). This does not compromise the Sagan's over-identification test as we fail to reject the null hypothesis that the instruments are valid, that is, uncorrelated with the error term.

Table 4 shows the first stage IV regression results, which offers a justification for the validity of our instruments. We use two kinds of instrument, that is, the cost of enforcing contracts and weighted 5-year lag of average GLF. The selection of the first instrument is based on the ground that the decision of microfinance commercial investors, especially international funders, on whether to invest in a particular country is likely to depend on the extent to which the country has a good institution (e.g., represented by a low cost of enforcing contracts) that would facilitate economic activities (Imai et al., 2012). In this context, the cost of enforcing contracts is supposed to have a significant and negative correlation with MFIs' GLF per capita.

In summary, our main findings show that MFIs improve income inequality. This result is further corroborated by the pooled OLS and RE regressions provided in Table 3 . The empirical findings confirm that microfinance intensity contributes directly and positively to not only narrowing the gap between the poor and the rich, but also reducing income inequality at the macro level. On the other hand, an increase in the degree of GLF per capita significantly reduces, and therefore improves, income distribution in developing countries. This result is somewhat logical since, according to the literature on the subject, informal financial sector, especially small-scale non-collateral loans, affects standards of living for low-income households. However, we believe that the differences recorded in terms of the impact of microfinance on income inequality between regions

Table 4 First stage IV regression results

\begin{tabular}{ll}
\hline Variables & Coefficients \\
\hline W5lag_GLF & $0.20^{* * *}(3.41)$ \\
CE & $-0.04^{* * *}(-3.22)$ \\
GDP & $-0.19(-0.64)$ \\
DCP & $0.007(-0.97)$ \\
TRADE & $0.016^{* *}(2.54)$ \\
Constant & $3.54(1.37)$ \\
Observations & 57 \\
\hline
\end{tabular}

Dependent variable: lag of GLF per capita.w5lagGLF is the weighted 5 year average lag of gross loan portfolio. CE is the enforcing contracts at the country level.w5lag_GLF and GDP variables are in logarithm. Figures in brackets show $t$-statistic

** and ${ }^{* * *}$ Indicate significance at the 5 and $1 \%$ levels, respectively 
may be mainly due to two reasons. First, we think that it can be explained by the differences in the degree of financial development and economic growth, which are influenced by other factors, such as the legislative tradition of the country, the nature of political systems, available in an economy and other factors specific to each country. Second this region has difficulty in controlling social and ethnic unrest, which eventually turns into violence and conflict (Bel hadj Miled \& Ben Rejeb, 2018; Imai et al., 2012).

Our empirical results are also consistent with those obtained by Kai and Hamori (2009), who found that the intensity of microfinance has a significant equalization effect and reduces inequality. The result is also similar to the findings of Khandker (2005) and Mahjabeen (2008) that found that microfinance helps reduce extreme poverty rather than moderate poverty, while also reducing income inequality in Bangladesh.

\section{Conclusion and policy implications}

Identifying the vital role played by MFIs in reducing both poverty and inequality is a matter of great concern for the poor countries-where combating poverty/inequality is the 2030 development agenda of the United Nations Millennium Development Goals (MDGs). Many researchers (e.g., Banerjee et al., 2015; Clarke et al., 2006; Fishman, 2012; Gimet \& Lagoarde-Segot, 2011; Hossain \& Knight, 2008; Li et al., 1998), have argued that because formal financial systems in developing countries are still incomplete and deficient, the majority of people do not have access to the basic financial services. Moreover, many people worry that financial development benefits only the rich. Since, financial markets are fraught with adverse selection and moral hazard problems, borrowers need collateral. The poor, who do not have this, might, therefore, find it difficult to get loans even when financial markets are well developed, it might worsen inequality. In these circumstances, microfinance may play an important role to benefit poor people and making more money available to low-income households.

Therefore, in this paper, we attempt to examine the effectiveness of microfinance participation on income inequality by using cross-sectional data covering 596 MFIs for 2013, supplemented by a two-period (2000-2006 and 2007-2013) panel data of 57 developing countries in 1132 MFIs. This study adopts panel data methodologies, such as ordinary least square (OLS), pooled ordinary least square (POLS) and instrumental variables (IV) estimations to overcome the endogeneity problem among the variables. The empirical results confirm that countries with higher MFIs' gross loan portfolio per capita tend to have lower income inequality, which confirms the beneficial outcome of microfinance in reducing inequality at the macro level. Moreover, our results suggest that microfinance loans can lead to improve the relative income position of the poor in developing countries. The results would be useful for development agencies, governments, and other practitioners in developing countries. Indeed, microfinance can play a crucial role for reducing that country's inequality, and opening an opportunity for low-income borrowers to play a significant role in economic development and thus to increase their income and well-being. 
These findings lend support to the suggestion that microfinance is an appropriate tool to reducing income inequality gap between the poor and the rich in developing countries. It thus seems to have the potential to help poor people directly, as it enables them to engage in self-employment and play an active role in the economy. Since microfinance specifically targets the poor and economically excluded, it provides these people with new financial opportunities to initiate or maintain income-generating activities, thereby increasing their income and well-being, and effectively reducing income inequality. Over time, these micro-entrepreneurs will need more credit to continue to grow their small businesses. When these micro-entrepreneurs obtain higher levels of microcredit and increasingly use other auxiliary microfinance services, such as nutrition and health or women's empowerment, these investments may generate more income in the medium term and participate in reducing income inequality. Therefore, policymakers' intervention is necessary, as they could generate suitable strategies to ensure more direct contact with microfinance and the banks for facilitate institutions providing financial services to the poor.

\section{Appendix}

See Table 5.

Table 5 List of countries

\begin{tabular}{|c|c|c|c|c|c|}
\hline \multicolumn{2}{|l|}{ Low income } & \multicolumn{2}{|c|}{ Lower-middle income } & \multicolumn{2}{|l|}{ Upper-middle income } \\
\hline Countries & Region & Countries & Region & Countries & Region \\
\hline Bangladesh & SA & Egypt & MENA & Jordan & MENA \\
\hline Nepal & SA & Pakistan & SA & Morocco & MENA \\
\hline Benin & SSA & Cameroon & SSA & Cambodia & EAP \\
\hline Burkina Faso & SSA & Sierra Leone & SSA & China & EAP \\
\hline Congo, Dem. Rep & SSA & Senegal & SSA & Argentina & EAP \\
\hline Ethiopia & SSA & Nigeria & SSA & Bolivia & EAP \\
\hline Mozambique & SSA & Zambia & SSA & Chile & EAP \\
\hline Rwanda & SSA & India & EAP & Dominican Republic & EAP \\
\hline Tanzania & SSA & Indonesia & EAP & Jamaica & $\mathrm{ALC}$ \\
\hline Mali & SSA & Philippines & EAP & Panama & ALC \\
\hline Madagascar & SSA & Vietnam & EAP & Peru & $\mathrm{ALC}$ \\
\hline Malawi & SSA & El Salvador & ALC & Mexico & $\mathrm{ALC}$ \\
\hline Uganda & SSA & Guatemala & $\mathrm{ALC}$ & Brazil & $\mathrm{ALC}$ \\
\hline Haiti & ALC & Honduras & $\mathrm{ALC}$ & Colombia & $\mathrm{ALC}$ \\
\hline Kyrgyz Republic & ECA & Nicaragua & $\mathrm{ALC}$ & Costa Rica & $\mathrm{ALC}$ \\
\hline \multirow[t]{7}{*}{ Tadjikistan } & ECA & Paraguay & $\mathrm{ALC}$ & Albania & ECA \\
\hline & & Armenia & ECA & Azerbaijan & ECA \\
\hline & & Moldova & ECA & Bosnia and Herzegovina & ECA \\
\hline & & Georgia & ECA & Kazakhstan & ECA \\
\hline & & & & Romania & ECA \\
\hline & & & & Russian Federation & ECA \\
\hline & & & & Serbia & ECA \\
\hline
\end{tabular}

MENA Middle East and North Africa, SA South Asia, SSA Sub-Saharan Africa; EAP East Asia and Pacific, LAC Latin America and Caribbean, ECA Europe and Central Asia 


\section{Abbreviations}

OLS: Ordinary least square; 2SLS: Two-stage least squares; POLS: Pooled ordinary least square; IV: Instrumental variables; MFI: Microfinance United Nations Millennium Development Goals (MDGs); ECA: Europe and Central Asia; EAP: East Asia and Pacific; LAC: Latin America and Caribbean; SA: South Asia; SSA: Sub-Saharan Africa; MENA: Middle East and North Africa; MIX: Microfinance information exchange; GLF: Microcredit gross loan portfolio; INEQ: Income inequality; Trade openness: TRADE; GDP: Gross Domestic Product; DCP: Domestic credit to private sector by banks to GDP ratio; CE: Enforcing contracts at the country level; Inw5lagGLF: Weighted 5-year average lag of GLF, which is weighted by the number of MFIs for each country; FE: Fixed effect; RE: Random effect.

\section{Acknowledgements}

We are grateful to the Editor and two anonymous reviewers for their insightful comments and suggestions

\section{Authors' contributions}

All authors have contributed equally to all aspects of the research. All authors read and approved the final manuscript.

\section{Funding}

The authors have not received funding from any organization.

\section{Availability of data and materials}

The data that support the findings of this study are available from the corresponding author upon reasonable request. The data are not publicly available due to privacy or ethical restrictions.

\section{Declarations}

\section{Competing interests}

The authors declares no competing interests.

\section{Author details}

${ }^{1}$ Department of Business Administration, College of Science and Arts, Shaqra University, Sajir, Saudi Arabia. ${ }^{2}$ Laboratory of Management of Innovation and Sustainable Development (LAMIDED), University of Sousse, Sousse, Tunisia. ${ }^{3}$ Department of Business Administration, College of Science and Humanities, Shaqra University, Al-Dawadmi 11911, Saudi Arabia. ${ }^{4}$ Department of Economics, Higher Institute of Finance and Taxation, University of Sousse, Sousse, Tunisia. ${ }^{5}$ Department of Basic Sciences, Deanship of Preparatory Year and Supporting Studies, Imam Abdulrahman Bin Faisal University, P.O. Box 1982, Dammam 34212, Saudi Arabia.

Received: 5 February 2021 Accepted: 12 January 2022

Published online: 25 January 2022

\section{References}

Afrane, S. (2002). Impact assessment of microfinance interventions in Ghana and South Africa: A synthesis of major impacts and lessons. Journal of Microfinance, 4(1), 37-58.

Ahlin, C., \& Jiang, N. (2008). Can micro-credit bring development? Journal of Development Economics, 86, 1-12.

Ali, I. A. M., \& Ghoneim, H. (2019). The effect of microfinance on income inequality: Perspective of developing countries. Journal of Economics and Management, 35(1), 41-62.

Arif, M., Ismail, M., \& Santoso, D. B. (2019). Does microfinance affect poverty reduction and inequality in Indonesia? International Journal of Scientific and Technology Research, 8(4), 122-125.

Armendariz de Aghion, B., \& Morduch, J. (2005). The Economics of Microfinance (p. 352). The Mit Press Cambridge.

Bakhtiari, S. (2011). Microfinance and poverty reduction: Some international evidence. International Business and Economics Research Journal, 5(12), 65-71.

Banerjee, A. B., Duflo, E., Glennerster, R., \& Kinnan, C. G. (2015). The miracle of microfinance? Evidence from a randomized evaluation. American Economic Journal: Applied Economics, 7(1), 22-53.

Banerjee, A. B., \& Jackson, L. (2017). Microfinance and the business of poverty reduction: Critical perspectives from rural Bangladesh. Human Relations, 70(1), 63-91.

Banerjee, A. V., \& Newman, A. F. (1993). Occupational choice and the process of development. Journal of Political Economy, $101(2), 274-298$

Bangoura, L., Mbow, M. K., Lessoua, A., \& Diaw, D. (2016). Impact of microfinance on poverty and inequality A heterogeneous panel causality analysis. Revue D'economie Politique, Dalloz, 126(5), 789-818.

Barnes, C. (1996). Assets and the impact of micro-enterprise finance programs. AIMS paper. Management Systems International.

Beck, T., \& Demirgüç-Kunt, A. (2008). Access to finance: An unfinished agenda. World Bank Economic Review, 22, 383-396. Beck, T., Demirguc-Kunt, A., \& Levine, R. (2004). Finance, inequality and poverty: Cross-country evidence. World Bank Policy Research Working Paper 3338. Washington: World Bank.

Beck, T., Demirguç-Kunt, A., \& Levine, R. (2007). Finance, inequality and the poor. Journal of Economic Growth, 12(1), 27-49.

Beck, T., \& Levine, R. (2002). Industry growth and capital allocation: Does having a market- or bank-based system matter? Journal of Financial Economics, 64, 147-180.

Bel hadj Miled Ben Rejeb, K. J. (2018). Can microfinance help to reduce poverty? A review of evidence for developing countries. Journal of the Knowledge Economy, 9, 613-635.

Besley, T., \& Burgess, R. (2003). Halving global poverty. Journal of Economic Perspectives, 17, 3-22.

Bhargava, V. (2006). Global issues for global citizens: An introductory to key development challenges. World Bank. 
Bourguignon, F. (2004) The poverty-growth-inequality triangle, New Delhi Working Papers No 125. Retrieved November 11, 2013 from http://www.icrier.org/pdf/wp125.pdf.

Castells-Quintana, D., Larrú, J. M., \& Lacalle-Calderón, M. (2019). Aid, microfinance and income inequality: A global view. Revista De Economía Mundial, 52, 143-174.

Clarke, G. R., Xu, L. C., \& Zou, H.-F. (2006). Finance and income inequality: What do the data tell us? Southern Economic Journal, 72(3), 578-596.

Cull, R., Demirgüç-Kunt, A., \& Morduch, J. (2011). Does regulatory supervision curtail microfinance profitability and outreach? World Development, 39(6), 949-965.

Cuong, N. V. (2007). Impact of micro-credit on poverty and inequality: The case of the Vietnam Bank for Social Policies (Doctoral dissertation). Hanoi, Viatnam: National Economics University.

Dabla-Norris, E., Ji, Y., Townsend, R. M., \& Filiz Unsal, D. (2015). Distinquishing constraints of financial inclusion and their impact on GDP and inequality (NBER Working Paper No. 20821). National Bureau of Economic Research, Cambridge, MA.

Delbianco, F., Dabús, C., \& Caraballo, M. A. (2014). Income inequality and economic growth: New evidence from Latin America. Cuadernos De Economia, 33(63), 381-398.

Dollar, D., \& Kraay, A. (2002). Growth is good for the poor. Journal of Economic Growth, 7(3), 195-225.

Dreher, A., \& Gaston, N. (2008). Has globalization increased inequality? Review of International Economics, 16(3), 516-536.

Fishman, J. (2012). Microfinance -is there a solution? A survey on the use of MFIs to alleviate poverty in India. Denver Journal of International Law \& Policy, 40(4), 588-619.

Franco, C., \& Gerussi, E. (2013). Trade, foreign direct investments (FDI) and income inequality: Empirical evidence from transition countries. The Journal of International Trade \& Economic Development, 22(8), 1131-1160.

Ghosh, J. (2013). Microfinance and the challenge of financial inclusion for development. Cambridge Journal of Economics, 37, 1203-1219.

Gibbons, D. S., \& Meehan, J. W. (2002). Financing Microfinance for Poverty Reduction. Draft Paper Commissioned by the Microcredit Summit Campaign, CASHPOR Financial and Technical Services, Malaysia

Gimet, C., \& Lagoarde-Segot, T. (2011). A closer look at financial development and income distribution. Journal of Banking \& Finance, 35, 1698-1713.

Hamori, S., \& Hashiguchi, Y. (2012). The effect of financial deepening on inequality: Some international evidence. Journal of Asian Economics, 23(4), 353-359.

Hermes, N. (2014). Does microfinance affect income inequality? Applied Economics, 46(9), 1021-1034.

Herzer, D., \& Vollmer, S. (2012). Inequality and growth: Evidence from panel cointegration. Journal of Economic Inequality, 10(4), 489-503.

Hossain, F., \& Knight, T. (2008). Financing the Poor: Can microcredit make a difference? Empirical observations from Bangladesh. Brooks World Poverty Institute (BWPI) Working Paper No. 38.

Hulme, D., \& Mosley, P. (1996). Finance against poverty, Vols. 1 and 2. London: Routledge.

Imai, K. S., Gaiha, R., Thapa, G., \& Annim, S. K. (2012). Micro-finance and poverty: A macro perspective. World Development, 40(8), 1675-1689.

Jalilian, H., \& Kirkpatrick, C. (2005). Does financial development contribute to poverty reduction? Journal of Development Studies, 41, 636-656.

Jauch, S., \&Watzka, S. (2016). Financial development and income inequality: A panel data approach. Empirical Economics, $51,291-314$.

Johnson, S., \& Rogaly, B. (1997). Microfinance and Poverty Reduction. Oxfam and Action Aid, London. https://doi.org/10. $3362 / 9780855988005$

Kabeer, N. (2005). Is Microfinance a'Magic Bullet'for Women's Empowerment? Analysis of Findings from South Asia. Economic and Political Weekly, 40(44/45), 4709-4718.

Kai, H., \& Hamori, S. (2009). Microfinance and Inequality. Research in Applied Economics, 1(1), 1-12.

Khandker, S. R. (2005). Micro-finance and poverty: Evidence using panel data from Bangladesh. The World Bank Economic Review, 19(2), 263-286.

Kim, D.-H., \& Lin, S.-C. (2011). Nonlinearity in the financial development-income inequality nexus. Journal of Comparative Economics, 39, 310-325.

Kleibergen, F., \& Paap, R. (2006). Generalized reduced rank tests using the singular rvalue decomposition. Journal of Econometrics, 127, 97-126.

Kumar, A. (2016). Does microfinance redefine identity, income and insecurity among rural women? A model of women's empowerment. Enterprise Development and Microfinance, 27(3), 192-203.

Lacalle-Calderon, M., Larrú, J. M., Garrido, S. R., \& Perez-Trujillo, M. (2019). Microfinance and income inequality: New macro-level evidence. Review of Development Economics, 23(2), 860-876.

Li, H., Squire, L., \& Zou, H.-F. (1998). Explaining International and Intertemporal Variations in Income Inequality. The Economic Journal, 108(446), 26-43.

Mahjabeen, R. (2008). Microfinancing in Bangladesh: Impact on households, consumption and welfare. Journal of Policy Modeling, 30(6), 1083-1092.

McKenzie, D., \& Woodruff, C. (2008). Experimental evidence on returns to capital and access to finance in Mexico. World Bank Economic Review, 22, 457-482

MerslandØystein Strøm, R. R. (2012). The past and future of innovations in microfinance. Oxford Handbooks Online. https://doi.org/10.1093/oxfordhb/9780195391244.013.0028

Milanovic, B. (2002). Can we discern the effect of globalization on income distribution? Evidence from household budget survey. World Bank Policy Research, Working Paper 2876

Milanovic, B. (2014). All the Ginis dataset. World Bank, Washington, D.C. Retrieved from http://data.worldbank.org/datacatalog/all-the-ginis

Morduch, J., \& Haley, B. (2002). Analysis of the Effects of Microfinance on Poverty Reduction, NYU Wagner Working Paper No. 1014, June.

Odell, K. (2010). Measuring the impact of microfinance: Taking another look. Grameen Foundation. 
Ravallion, M. (2005). Inequality is bad for the poor, Policy research working paper 3677. World Bank.

Reuveny, R., \& Li, Q. (2003). Economic openness, democracy, and income inequality. Comparative Political Studies, 36(5), 575-601.

Roodman, D., \& Jonathan, M. (2014). The impact of microcredit on the poor in Bangladesh: Revisiting the evidence. Journal of Development Studies, 50(4), 583-604.

Shahbaz, M., Bhattacharya, M., \& Mahalik, M. K. (2017). Finance and income inequality in Kazakhstan: Evidence since transition with policy suggestions. Applied Economics, 49(52), 5337-5351

Silva, J. A. (2007). Trade and income inequality in a less developed country: The case of Mozambique. Economic Geography, 83(2), 111-136.

Soubbotina, T., \& Sheram, K. (2000). Beyond economic growth: meeting the challenges of global development. World Bank.

Stewart, R., \& Moslares, C. (2012). Income inequality and economic growth: The case of Indian states 1980-2010. Cuadernos De Economia, 31(57), 41-64.

Stiglitz, J. E. (2012). The price of inequality: How today's divided society endangers our future (p. 2012). W. W. Norton \& Company.

Tchouassi, G. (2011). Microfinance, inequality and vulnerability: Empirical analysis from Central African countries. Journal of Development and Agricultural Economics, 3(4), 150-156.

World Bank. (2013). World Development Indicators database, World Bank, Washington DC. Retrieved from https://data. worldbank.org/data-catalog/world-development-indicators

Younsi, M., \& Bechtini, M. (2018). Economic growth, financial development, and income inequality in BRICS countries: Does kuznets' inverted U-shaped curve exist? Journal of the Knowledge Economy. https://doi.org/10.1007/ s13132-018-0569-2

Younsi, M., Khemili, H., \& Bechtini, M. (2019). Does foreign aid help alleviate income inequality? New evidence from African countries. International Journal of Social Economics, 46(4), 549-561.

Zhu, S. C., \& Trefler, D. (2005). Trade and inequality in developing countries: A general equilibrium analysis. Journal of International Economics, 65(1), 21-48.

\section{Publisher's Note}

Springer Nature remains neutral with regard to jurisdictional claims in published maps and institutional affiliations.

\section{Submit your manuscript to a SpringerOpen ${ }^{\circ}$ journal and benefit from:}

- Convenient online submission

Rigorous peer review

Open access: articles freely available online

- High visibility within the field

- Retaining the copyright to your article

Submit your next manuscript at $\boldsymbol{s p r i n g e r o p e n . c o m ~}$ 